\title{
Penapisan Fitokimia dan Kapasitas Antibakteri Minyak Eteris Daun Akway (Drimys piperita Hook f.)
}

\section{Phytochemical Screening and Antibacterial Activity of Essential oil of Akway (Drimys piperita Hook f.) Leaves}

\author{
${ }^{1}$ Herlina Enika Dewi Mambrasar, ${ }^{* 2}$ Gino Nemesio Cepeda, ${ }^{2}$ Meike Meilan Lisangan \\ ${ }^{1}$ Alumni Jurusan Teknologi Pertanian, Universitas Papua \\ ${ }^{2}$ Jurusan Teknologi Pertanian, Universitas Papua \\ Jl. Gunung Salju Amban, Manokwari 98314. \\ "Email: ginocepeda.gc@gmail.com
}

\begin{abstract}
Akway (Drimys piperita) is an aromatic plant used by local society in Arfak Mountains Regency to enhance vitality of body. The plant contains a number of essential oil in parts of leaves and barks. Essential oils had been prooved having strong antibacterial capacity. Phytochemicals content of essential oil highly determined its antibacterial capacity. The research was focused to determine phytochemicals content and antibacterial capacity of essential oil of akway leaves. Distillation process of akway leaves essential oil was performed by using water distillation method whereas its phytochemicals contents were determined qualitatively on compounds of terpenoids, saponines, alkaloids and flavonoids. Antibacterial capacity assay was done using disc diffusion assay to Pseudomonas aeruginosa, Bacillus cereus, Escherichia coli and Staphyloccocus aureus. The result shows that essential oil of akway leaves contains compound of terpenoids as major compounds, saponines and flavonoids. Leaves eteris oil of akway have antibacterial capacity to tested bacteria with minimum inhibitory concentrations in range of $0.042 \%-0.5 \%$.
\end{abstract}

Keywords: Phytochemical, antibacterial, essential oil, Drimys piperita leaves.

\begin{abstract}
Abstrak
Akway (Drimys piperita) merupakan tumbuhan aromatik yang digunakan masyarakat lokal Kabupaten Pegunungan Arfak sebagai tumbuhan obat untuk meningkatkan vitalitas tubuh. Tumbuhan ini mengandung minyak eteris pada bagian daun dan kulit batangnya. Minyak eteris telah dibuktikan memiliki kapasitas antibakteri yang kuat. Kandungan fitokimia minyak eteris sangat menentukan kapasitas antibakterinya. Penelitian ini ditujukan untuk menentukan kandungan fitokimia dan kapasitas antibakteri minyak eteris daun akway. Proses penyulingan minyak eteris daun akway dilakukan dengan menggunakan metode penyulingan air sedangkan kandungan fitokimianya ditentukan secara kualitatif terhadap kelompok senyawa terpenoid, saponin, alkaloid dan flavonoid. Kapasitas antibakteri ditentukan dengan metode difusi cakram terhadap bakteri Pseudomonas aeruginosa, Bacillus cereus, Escherichia coli dan Staphyloccocus aureus. Hasil pengujian menunjukkan bahwa minyak eteris daun akway mengandung terpenoid sebagai senyawa penyusun terbesar, saponin dan flavonoid. Minyak eteris daun akway memiliki kapasitas antibakteri terhadap bakteri uji dengan konsentrasi hambat minimum 0,042\%-5\%.
\end{abstract}

Kata kunci: fitokimia, antibakteri, minyak eteris, daun Drimys piperita 


\section{PENDAHULUAN}

Tumbuhan aromatik telah digunakan sejak awal peradaban manusia untuk memberikan flavor pada pangan, menghilangkan bau, serta untuk mengendalikan masalah kesehatan (Franzs, 2010). Beberapa bagian tumbuhan aromatik seperti bunga, daun, batang, biji, buah, akar atau kulit batang mengandung sejumlah minyak eteris (Sezen dkk., 2019). Minyak eteris pada prinsipnya berbentuk cairan, jernih dan jarang memiliki warna dengan karakterisitik aroma yang kuat (Andrade dkk., 2014). Minyak eteris tersusun dari campuran senyawa yang bervariasi yang umumnya terdiri dari terpenoid, hidrokarbon alifatik rantai pendek, asam, alkohol, aldehid, ester atau lakton asiklik, senyawa yang mengandung nitrogen dan sulfur, coumarin dan homolog fenilpropanoid (Saranraj dan Devi, 2017). Senyawa-senyawa tersebut disintesis oleh tumbuhan aromatik sebagai senyawa metabolit sekunder untuk melindungi tumbuhan dari serangan mikroorganisme dan serangga (Andrade dkk., 2014).

Drimys piperita Hook f. yang disebut "Akway" oleh masyarakat lokal Pengunungan Arfak merupakan tumbuhan aromatik yang memiliki kulit batang berwarna coklat kemerahan dengan daun yang tebal dan hijau sepanjang tahun. Tumbuhan ini oleh masyarakat lokal Pegunungan Arfak digunakan untuk meningkatkan vitalitas tubuh dan mengobati malaria (Cepeda dkk., 2011a). Sebagai tumbuhan aromatik akway mengandung minyak eteris pada bagian batang dan daunnya. Kandungan minyak eteris kulit batang akway mencapai $0,37 \%$ sedangkan pada bagian daunnya sebesar $0,20 \%$ (Zakariyah dkk., 2018; Cepeda dkk., 2011a). Jenis senyawa volatil yang terdapat dalam minyak eteris kulit batang akway diantaranya adalah $\alpha$-pinen $20,24 \%, \beta$-pinen $14,88 \%$ dan 4-terpineol 13,16\% (Cepeda dkk., 2011b) sedangkan senyawa volatil pada bagian daun akway sebagian besar terdiri dari senyawa linalool 17,12\%, biformen 12,65\%, $\alpha$-pinen $6,59 \%, \beta$-pinen 7,35\% (Cepeda dkk., 2011a).

Minyak eteris daun tumbuhan aromatik dilaporkan memiliki aktivitas antibakteri yang kuat terhadap pertumbuhan bakteri Gram positif maupun Gram negatif. Minyak eteris daun Thymus numidicus dilaporkan memiliki aktivitas antibakteri terhadap pertumbuhan bakteri Gram negatif Escherichia coli dan Pseudomonas aeruginosa serta Gram positif Staphylococcus aureus (Messara dkk., 2017). Minyak eteris daun Laurus nobilis dan Cymbopogon nardus bersifat antibakteri kuat terhadap pertumbuhan Bakteri Gram negatif $E$. coli dan $P$. aeruginosa serta bakteri Gram positif Bacillus cereus dan $S$. aureus (Fidan dkk., 2019; Wibowo dkk., 2018).

Komposisi fitokimia dan konsentrasi minyak eteris sangat menentukan kapasitas antibakterinya. Minyak eteris dengan kandungan fenol terbesar memiliki kapasitas antibakteri paling kuat, kemudian diikuti oleh terpen alkohol, keton dan ester (Perricone dkk., 2015). Disamping itu juga galur bakteri memiliki ketahanan berbeda-beda terhadap minyak eteris. Oleh sebab itu penelitian ini bertujuan untuk mengetahui komposisi fitokimia, pengaruh konsentrasi minyak eteris daun akway terhadap pertumbuhan beberapa bakteri Gram posisitf dan Gram negatif.

\section{METODOLOGI}

\section{Bahan dan Alat}

Bahan penelitian utama penelitian ini yaitu daun akway dan bahan-bahan lainnya yaitu bahan-bahan untuk keperluan analisis kualitatif fitokimia dan bahan-bahan untuk pengujian kapasitas antibakteri. Bahan-bahan untuk analisis fitokimia yaitu $\mathrm{CHCl}_{3}, \mathrm{C}_{4} \mathrm{H}_{6} \mathrm{O}_{3}$, $\mathrm{H}_{2} \mathrm{SO}_{4}$ dan pereaksi Dragendorf sedangkan bahan-bahan untuk analisis kapasitas antibakteri, yaitu kultur bakteri Escherichia coli, Bacillus cereus, Pseudomonas aeruginosa dan Staphylococcus aureus yang diperoleh dari Balai Veteriner Bogor, nutrient broth (NB) dan nutrient agar (NA) yang berasal dari oxoid, $\mathrm{NaCl}$ dari Merck dan $\mathrm{C}_{2} \mathrm{H}_{5} \mathrm{OH}$ yang diperoleh dari JT Baker.

Peralatan yang digunakan dalam penelitian ini adalah peralatan disitilasi minyak eteris dan peralatan pengujian kapasitas antibakteri meliputi kertas saring Whatman no 1, cawan petri, laminar air flow (LAF), hot plate, inkubator, mikropipet, tips, vorteks, caliper dan peralatan gelas lainnya.

\section{Metode}

Pelaksanaan penelitian ini menggunakan metode eksperimen dengan rancangan penelitian menggunakan rancangan acak kelompok (RAK). Konsentrasi minyak eteris sebesar $0,2,4,6,8$ dan $10 \%$ merupakan 
perlakuan yang akan diuji pada 4 kelompok bakteri uji, yaitu $P$. aeruginosa, B. cereus, E. coli dan S. aureus.

\section{Pembuatan bubuk daun}

Daun akway yang digunakan dalam penelitian ini adalah daun akway yang berasal dari pohon akway dengan diameter batang utama $\pm 10 \mathrm{~cm}$ yang diperoleh dari Distrik Anggi, Kabupaten Pegunungan Arfak Papua Barat. Daun akway dicuci bersih dengan air mengalir kemudian dikering-anginkan. Selanjutnya daun akway dikering-anginkan di dalam ruangan yang dilengkapi dengan air conditioner suhu $18^{\circ} \mathrm{C}$. Daun akway dikeringkan sampai kadar air 10-12\%. Penggilingan daun akway kering dilakukan menggunakan hammer mill dan pengayakan menggunakan ayakan 40 mesh. Bubuk daun akway yang dihasilkan dikemas menggunakan plastik (Cepeda dkk., 2011a).

\section{Distilasi minyak eteris daun akway}

Proses distilasi minyak eteris daun akway dilakukan dengan metode distilasi air (Cepeda dkk., 2019). Sebanyak 200 g bubuk daun akway dimasukkan dalam labu distilasi kemudian ditambahkan air sebanyak $900 \mathrm{ml}$, kemudian labu distilasi dihubungkan dengan kondensor pada alat distilasi. Bagian ujung kondensor lainnya dihubungkan dengan labu penampung hasil distilasi. Kondensor dialiri dengan air mengalir menggunakan pompa. Campuran bubuk daun akway dan air di dalam labu distilasi selanjutnya dipanaskan menggunakan hot plate sampai air distilat tidak mengandung minyak eteris. Hasil distilasi yang tertampung dipisahkan minyak eterisnya menggunakan labu pemisah minyak.

\section{Rendemen minyak eteris}

Penentuan rendemen minyak eteris bubuk daun akway dilakukan dengan menggunakan formula sebagai berikut (Cepeda dkk., 2011b): Rendemen minyak eteris $=\left(\frac{\text { volume minyak eteris }(\mathrm{ml})}{\text { berat bubuk daun akway }(\mathrm{g})}\right) \times 100 \%$

\section{Pengujian kualitatif kandungan fitokimia}

Pengujian fitokimia minyak eteris dilakukan terhadap kelompok senyawa terrpenoid, saponin, alkaloid dan flavonoid. Pengujian kandungan senyawa golongan terpenoid dan flavonoid masing-masing dilakukan dengan metode anhidrida asetat dan pereaksi asam sulfat pekat (Harbone, 1996), sedangkan senyawa kelompok saponin dan alkaloid masing-masing menggunakan metode uji pembentukaan busa dan uji Dragendorf (Tiwari dkk., 2011).

\section{Persiapan kultur bakteri}

Vial isolat bakteri dibuka secara aseptik di dalam LAF dan ditambahkan dengan $1 \mathrm{ml}$ medium NB steril. Campuran kultur bakteri dan NB diaduk menggunakan vorteks sampai tercampur sempurna. Campuran tersebut dipindahkan ke dalam tabung reaksi yang berisi $10 \mathrm{ml} \mathrm{NB}$ steril menggunakan mikropipet. Tabung reaksi yang berisi kultur bakteri dimasukkan ke dalam inkubator dengan suhu $37^{\circ} \mathrm{C}$ dan diinkubasi selama 24 jam. Kultur yang tumbuh dalam medium NB diinokulasi pada permukaan agar miring NA dan diinkubasi kembali selama 24 jam. Kultur dalam medium agar miring siap digunakan dalam pengujian aktivitas antibakteri (Cepeda dkk., 2015)

\section{Kapasitas antibakteri}

Pangujian kapasitas antibakteri dilakukan dengan menggunakan metode difusi cakram (Zakariyah dkk., 2018). Sebanyak 20 $\mathrm{ml}$ medium NA steril dituang ke dalam cawan petri steril hingga ketebalan $\pm 4 \mathrm{~mm}$. Setelah medium membeku, disimpan di dalam inkubator suhu $40^{\circ} \mathrm{C}$ selama 1-2 hari sampai tidak terlihat uap air pada cawan petri. Pada permukaan medium agar dalam cawan petri dituang $100 \mu \mathrm{l}$ kultur bakteri uji dengan jumlah sel $1 \times 10^{5} \mathrm{CFU} / \mathrm{ml}$ yang berasal dari kultur medium NB. Kultur pada permukaan medium NA dalam cawan petri disebarkan merata dipermukaan medium dengan menggunakan pipa gelas berbentuk L. Kertas saring Whatman no 1 dengan diameter $6 \mathrm{~mm}$ (cakram) ditetesi dengan $15 \mu$ l larutan minyak eteris dalam alkohol sesuai dengan perlakuan konsentrasi, yaitu 0, 2, 4, 6, 8 dan 10\%. Cawan petri diinkubasi pada suhu $37^{\circ} \mathrm{C}$ selama 24 jam. Aktivitas antibakteri minyak eteris daun akway diukur berdasarkan zona bening yang terbentuk di sekeliling cakram menggunakan caliper.

\section{Konsentrasi hambat tumbuh minimum (KHTM)}

Penentuan nilai KHTM minyak eteris daun akway ditentukan melalui analisis regresi linear antara ln konsentrasi minyak eteris daun 
akway (ln $\mathrm{K}_{\mathrm{ma}}$ ) pada sumbu $\mathrm{X}$ dan kuadrat diameter zona hambat minyak eteris $\left(\mathrm{DZH}_{\mathrm{ma}}{ }^{2}\right)$ pada beberapa konsentrasi pada sumbu Y. Perpotongan antara persamaan regresi linear $\mathrm{Y}=\mathrm{a}+\mathrm{bX}$ dengan sumbu $\mathrm{X}$ adalah nilai $\mathrm{ln}$ $\mathrm{K}_{\mathrm{ma}}$ pada $\mathrm{Y}=0\left(\mathrm{DZH}_{\mathrm{ma}}{ }^{2}=0\right)$. Nilai KHTM yaitu $0.25 \mathrm{x} \mathrm{e}^{\mathrm{Kma}}$ (Cepeda dkk, 2019).

\section{Analisis data}

Data yang diperoleh dari hasil pengujian dianalisis secara tabulasi. Data hasil analisis ditampilkan dalam bentuk tabel dan grafik.

\section{HASIL DAN PEMBAHASAN}

\section{Rendemen minyak eteris}

Penentuan rendemen minyak eteris daun akway bertujuan untuk mengetahui kandungan minyak eteris yang dapat daun akway. Hasil menunjukkan bahwa kandungan minyak eteris daun Akway sebesar 0,18\%. Rendemen minyak eteris daun akway relatif lebih rendah dibandingkan dengan rendemen minyak eteris daun cengkeh dan daun kayu putih jenis Melaleuca cajuputi, yaitu masing-masing sebesar 1.2-1,84 dan 0,89\% (Jayanudin, 2011; Widiyanto dan Siarudin, 2013). Namun demikian kandungan minyak eteris daun akway masih lebih tinggi dibandingkan dengan rendemen minyak eteris daun kayu putih jenis Melaleuca viridiflora dan daun tembakau yang masing-masing rendemnnya sebesar jenis $<0,1 \%$ dan $0,13 \%$ (Widiyanto dan Siarudin, 2013; Sari dkk., 2018).

Perbedaan rendemen minyak eteris tumbuhan aromatik bergantung pada kemampuan tumbuhan mensintesis metabolit sekunder sebagai respon terhadap lingkungan. Menurut Duarte dkk. (2018), tumbuhan aromatik memproduksi minyak eteris sebagai metabolit sekunder sebagai respon stres fisiologik, serangan patogen dan faktor ekologi. Faktor lingkungan fisik dan kimia dapat mempengaruhi jumlah minyak eteris yang diproduksi oleh tumbuhan aromatik (Abdelmajeed dkk., 2013).

\section{Kandungan kelompok senyawa fitokimia}

Penapisan kelompok senyawa penyusun minyak eteris daun akway dilakukan untuk mengetahui kelompok senyawa penyusun utama minyak eteris daun akway. Hasil pengujian menunjukkan bahwa kelompok senyawa fitokimia dalam minyak eteris daun akway terdiri dari terpenoid, saponin dan flavonoid sedangkan kelompok senyawa alkaloid tidak terdapat dalam minyak eteris daun akway (Tabel 1).

Tabel 1. Kandungan kelompok senyawa fitokimia

\begin{tabular}{lc}
\hline Golongan Senyawa & Hasil Pengujian \\
\hline Terpenoid & +++ \\
Saponin & ++ \\
Alkaloid & - \\
Flavonoid & + \\
\hline Ketangan & +++ posif \\
\hline
\end{tabular}

Keterangan : +++ positif kuat, ++ positif, + positif lemah, - negatif

Tabel 1. juga menunjukkan bahwa kelompok senyawa terpenoid merupakan senyawa penyusun terbesar minyak eteris daun akway diikuti oleh kelompok senyawa saponin dan flavonoid. Menurut Freires dkk. (2015), minyak eteris merupakan campuran kompleks dari berbagai senyawa yang secara kimia merupakan senyawa turunan terpen dan terpenoid (isoprenoid), aldehid alifatik dan aromatik serta fenol dengan berat molekul rendah. Senyawa terpen dalam minyak eteris terdiri dari monoterpen, diterpen dan sesquiterpen (Saranraj dan Devi, 2017). Sedangkan senyawa terpenoid dalam minyak eteris terdiri dari senyawa terpen terhidrogenasi, dehidrogenasi dan oksigenasi (Yadav dkk., 2014).

Kelompok senyawa terpen dan terpenoid memiliki bioaktivitas sebagai antibakteri termasuk bakteri yang resisten terhadap antibiotik (Mahizan dkk., 2019). Disamping itu juga memiliki bioaktivitas sebagai antikanker dan antimalaria serta diuretik (Saxena dkk., 2013).

Kelompok senyawa saponin merupakan senyawa yang diproduksi oleh tumbuhan dalam bentuk glikosida steroid atau triterpen polisiklik (Thakur dkk., 2011). Saponin selain memiliki bioaktivitas antibakteri, antifungi dan antivirus juga bersifat meningkatkan imunitas, antikarsinogenik, menurunkan kandungan kolesterol dan gula darah (Desai dkk., 2009).

\section{Kapasitas antibakteri}

Pengujian kapasitas antibakteri minyak eteris daun akway dilakukan pada selang konsentrasi $0-10 \% \quad(\mathrm{v} / \mathrm{v})$. Pengujian ini ditujukan untuk mengkaji potensi antibakteri minyak eteris daun akway terhadap 
pertumbuhan beberapa bakteri patogen. Hasil pengamatan menunjukkan bahwa minyak eteris daun akway memiliki kapasitas menghambat pertumbuhan bakteri patogen $P$. aeruginosa, B. cereus, S. aureus dan E. coli masing-masing dengan kapasitas penghambatan sebesar 10,05-15,30 $\mathrm{mm}$, $10,06-20,13 \mathrm{~mm}, 15,07-19,70 \mathrm{~mm}$ dan $12,40-$ $17,77 \mathrm{~mm}$ (Gambar 1). Hasil analisis ragam menunjukkan bahwa konsentrasi minyak eteris daun akway berpengaruh nyata terhadap diameter zona penghambatan. Peningkatan konsentrasi minyak eteris daun akway cenderung meningkatkan diameter zona penghambatan terhadap pertumbuhan bakteri uji.

Kapasitas minyak eteris menghambat pertumbuhan bakteri disebabkan oleh fitokimia yang bersifat antibakteri yang terkandung dalam minyak eteris daun akway. Hasil pengujian kualitatif kandungan fitokimia minyak eteris daun akway menunjukkan bahwa minyak eteris daun akway mengandung senyawa terpenoid sebagai senyawa penyusun terbesar. Kelompok senyawa terpenoid dilaporkan memiliki bioaktivitas antibakteri yang kuat (Mahizan dkk., 2019). Selain itu juga Cepeda dkk., (2011a), melaporkan bahwa senyawa penyusun terbesar dalam minyak eteris daun akway adalah senyawa monoterpen linalool dengan konsentrasi sebesar 17,12\%. Monoterpen linalool dilaporkan memiliki kapasitas antibakteri yang kuat (Silva dkk., 2015

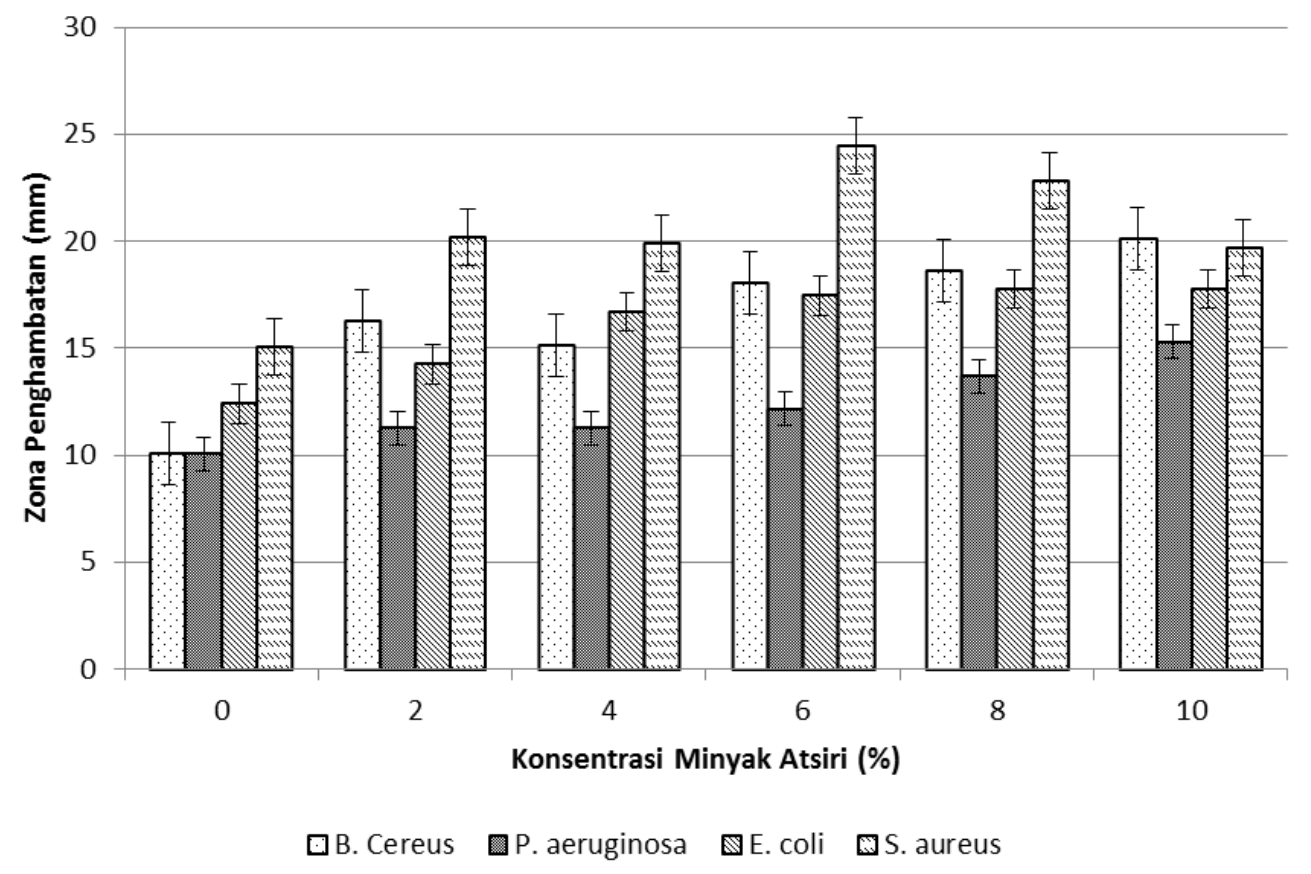

Gambar 1. Aktivitas antibakteri minyak volatil daun akway

Kapasitas antibakteri minyak eteris daun akway terhadap $B$. cereus dan $P$. aeruginosa cenderung meningkat dengan meningkatnya konsentrasi minyak eteris. Sedangkan kapasitas penghambatan minyak eteris daun akway terhadap $S$. aureus dan E. coli masing-masing optimal pada konsentrasi $6 \%$ dan $8 \%$. Peningkatan konsentrasi dari $6 \%$ menjadi $10 \%$ cenderung tidak meningkatkan kapasitas antibakteri minyak eteris terhadap bakteri E. coli. Sedangkan peningkatan konsentrasi dari $8 \%$ menjadi $10 \%$ cenderung menurunkan kapasitas antibakteri minyak eteris daun akway terhadap S. aureus.

Perbedaan pola penghambatan minyak eteris daun akway terhadap pertumbuhan bakteri uji, diduga disebabkan oleh perbedaan resistensi bakteri uji terhadap senyawa antibakteri yang terkandung dalam minyak eteris daun akway dan laju difusi minyak eteris dalam medium agar. Peningkatan konsentrasi minyak eteris dapat meningkatkan kapasitas 
antibakterinya (Seow dkk., 2014). Namun demikian faktor kelarutan minyak eteris dalam medium juga mempengaruhi laju difusi minyak eteris dalam medium agar. Minyak eteris memiliki kelarutan yang rendah dalam air (Saranraj dan Devi, 2017). Kelarutan minyak eteris yang rendah dan pengaruh perbedaan resistensi bakteri uji dapat menghasilkan pola penghambatan minyak eteris daun akway yang berbeda di dalam medium agar.

\section{Konsentrasi hambat tumbuh minimum (KHTM)}

KHTM minyak eteris daun akway merupakan konsentrasi terendah minyak eteris daun akway yang dapat menghambat pertumbuhan bakteri uji pada suatu medium. Hasil menunjukkan bahwa KHTM minyak eteris daun akway terhadap pertumbuhan bakteri patogen P.aeruginosa, B. cereus, E.coli dan S. aureus bervariasi antara 0,042\%-5,00\% (Tabel 2).

Tabel 2. KHTM minyak eteris kulit batang

\begin{tabular}{lc}
\multicolumn{1}{c}{ akway } & \\
\hline Jenis Bakteri & KHTM $(\%)$ \\
\hline B. cereus & 0,27 \\
P. aeruginosa & 5,00 \\
S. aureus & 0,04 \\
E.coli & 0,36 \\
\hline
\end{tabular}

Tabel 2. juga menunjukkan bahwa bakteri $B$. cereus dan $S$. aureus sebagai bakteri gram positif memiliki resistensi yang lebih rendah terhadap minyak eteris daun akway dibandingkan dengan bakteri gram negatif $E$. coli dan $P$. aeruginosa. Hasil tersebut menunjukkan bahwa bakteri gram negatif lebih tahan terhadap minyak eteris daun akway dibandingkan dengan bakteri gram positif.

Bakteri gram negatif cenderung memiliki resistensi yang lebih kuat terhadap minyak eteris daun akway disebabkan oleh perbedaan struktur dinding sel bakteri. Bakteri Gram negatif memiliki lapisan membran terluar (outer membrane) yang tersusun dari lipopolisakalida (LPS) yang berfungsi sebagai penghalang (barrier) masuknya senyawa antibakteri yang bersifat hidrofobik masuk ke dalam sel (Nazzaro dkk., 2013).

\section{KESIMPULAN}

Minyak eteris daun akway mengandung senyawa terpenoid sebagai senyawa penyusun terbesar, juga mengandung saponin dan flavonoid. Minyak eteris daun akway memiliki kapasitas antibakteri terhadap pertumbuhan bakteri $P$. aeruginosa, B. cereus, E. coli dan $S$. aureus dengan konsentrasi hambat tumbuh sebesar 0,042\%-5,00\%.

\section{DAFTAR PUSTAKA}

Abdelmajeed, N., Danial, E.N., \& Ayad, H.S. (2013). The effect of environmental stress on qualitative and quantitative essential oils of aromatic and medicinal plants. Archives des Sciences, 66(4): 100-119.

Andrade, B. F. M. T., Barbosa, L. N., Probst, I. S., \& Fernandes Jr. F. (2014). Antimicrobial activity of essential oils. Journal of Essential Oil Research, 2014 Vol. 26, No. 1, 34-40, http://dx.doi.org/10.1080/10412905.201 3.860409 .

Cepeda, G.N., Santoso, B.B., Lisangan, M.M. \& Silamba, I. $\left(2011^{\mathrm{a}}\right)$. Komposisi kimia minyak atsiri daun akway. Makara Sains 15(1): 63-66.

Cepeda, G.N., Santoso, B.B., Lisangan, M.M. \& Silamba, I. $\left(2011^{\text {b }}\right)$. Komposisi kimia minyak atsiri kulit kayu akway (Drimys piperita Hook f.). Bionatura 13(2) : 118124.

Cepeda, G.N., Lisangan, M.M. \& Silamba, I. (2015). Aktivitas antibakteri ekstrak kulit kayu akway (Drimys piperita Hook f.) terhadap bakteri patogen. Agritech 35(2):

170-177. doi:10.22146/agritech.9403.

Cepeda, G.N., Lisangan, M.M. \& Silamba, I. (2019). Aktivitas antibakteri minyak atsiri kulit kayu akway (Drimys piperita Hook. f.) pada beberapa tingkat konsentrasi, keasaman $(\mathrm{pH})$ dan kandungan garam. Jurnal Aplikasi Teknologi Pangan, 8 (4): 149-154.

Desai, S.D., Desaib, D.G., \& Kaurc, H. (2009). Saponins and their Biological Activities. Pharma Times, 41(3): 13-16.

Duarte, M.C.T., Duarte, R.M.T., Rodrigues, R.A.F., \& Rodrigues, M.V.N. (2018). Essential Oils and Their Characteristics. In S.M.B. Hashemi, A.M. Khaneghah, 
A. S. Sant'Ana, Editor. Essential Oils in Food Processing: Chemistry, Safety and Applications (pp. 1-19). USA: John Wiley \& Sons Ltd.

Freires, I. A., Denny, C., Benso, B.,A lencar, S. M. \& Rosalen, P., (2015).Antibacterial activity of essential oils and their isolated constituents against carcinogenic bacteria: A systematic review. Molecules, 20: 73297358.

Fidan, H., Stefanova, G., Kostova, I., Stankov, S. \& Damyanova, S. (2019). Chemical Composition and Antimicrobial Activity of Laurus nobilis L. Essential Oils from Bulgaria. Molecules 24(804):1-10 doi:10.3390/molecules24040804.

Franz, C.M. (2010). Essential oil research: Past, present and future. Flavour Fragrance Journal, 25: 112-113.

Harborne, J. B. (1996). Metode Fitokimia. Bandung :Penerbit ITB.

Jayanudin. (2011). Komposisi kimia minyak atsiridaun cengkeh dari proses penyulingan uap. Jurnal Teknik Kimia Indonesia, 10(1) : 37-42.

Mahizan, N. A., Yang, S-K., Moo, C-L., Song, A. A-L., Chong, C-M., Chong, C-W., Abushelaibi, A., Lim, S-H. E. \& Lai, KS. (2019). Terpene derivatives as a potential agent against antimicrobial resistance (AMR) pathogens. Molecules, 24: 2631.

Messara, Y., Fernane, F., \& Meddour, R. (2017). Chemical composition, antibacterial, and antifungal activities of the essential oil of Thymus numidicus Poiret from Algeria. Phytothérapie, 16:163-168. DOI 10.3166/phyto-20180044 .

Nazzaro, F., Fratianni, F., De Martino, L., Coppola, R., \& De Feo, V. (2013). Effect of essential oils on pathogenic bacteria. Pharmaceuticals, 6: 1451-1474.

Perricone, M., Arace, E., Corbo, M.R., Sinigaglia, M. \& Bevilacqua, A. (2015). Bioactivity of essential oils: a review on their interaction with food components. Frontiers in Microbiology, 6: 1-7.

Saranraj, P., \& Devi, V.D. (2012). Essential Oil and Its Antibacterial Properties - A Review. Life Science Archives (LSA), 3(2): $994-1011$.

Sari, N. K., Sumada, K., Ajiz, H. A. \& Fajarriani, W. Y. (2018). Atsiri oil production Of tobacco leaves by water distillation method. International Journal of Scientific \& Technology Research, 7 (2): 100-103.

Saxena, M., Saxena, J., Nema, R., Singh, D., \& Gupta, A. (2013). Phytochemistry of Medicinal Plants. Journal of Pharmacognosy and Phytochemistry, 1(6):168-182.

Seow, Y.X., Yeo, C.R., Chung, H.L. \& Yuk, H-G. 2014. Plant essential oils as active antimicrobial agents. Critical Reviews in Food Science and Nutrition 54:625-644.

Sezen, S., Gulluce, M., Kesmezcan, F. \& Alaylar, B. (2019). Essential oils and antimicrobial effects. International Journal of Scientific \& Engineering Research, 10 (9): 65-70.

Silva, V. A., Sousa, J. P., Guerra F. Q. S., Pessôa H. L. F., Freitas A. F. R., Coutinho, H.D.M., Alves L. B. N. \& Lima E. O. (2015). Antibacterial activity of the monoterpene linalool: Alone and in associationwith antibiotics against bacteria of clinical importance. International Journal of Pharmacognosy and Phytochemical Research, 7(5): 1022-1026.

Thakur, M., Melzig, M. F. Fuchs, H. \& Weng, A. (2011). Chemistry and pharmacology of saponins: special focus on cytotoxic properties. Botanics: Targets and Therapy, 1:19-29.

Tiwari, P., Kumar, B., Kaur, M., Kaur, G. \& Kaur, H. (2011). Phytochemical screening and extraction: A review. Sciencia, 1(1): 98-106.

Wibowo, D. P., Febriani, Y., Riasari, H. \& Aulifa, D. L. (2018). Chemical composition, antioxidant and antibacterial activities of the essential oils of medicinal plant Cymbopogonnardus from Lembang West Java. Research Journal of Chemistry and Environment, 22 (Special Issue I): 1-4.

Widiyanto, A., \& Siarudin, M. (2014). Sifat fisikokimia minyak kayu putih jenis Asteromyrtus brasii. Jurnal Penelitian Hasil Hutan, 32(4): 243-252.

Yadav, N., Yadav, R., \& Goyal, A. (2014). Chemistry of Terpenoids. International Journal of Pharmaceutical Sciences Review and Research, 27(2): 272-278. 
Zakariyah, M., Cepeda, G. N. \& Hutasoit, H. (2018). Sifat fisik, kandungan fitokimia dan aktivitas antibakteri minyak essensial kulit batang akway (Drimys piperita Hook f.). J. Agritechnology, 1(2): 56-65. 